Кліпкова О. І., к.е.н., доцент

Університет банківської справи м. Львів, Україна

DOI: https://doi.org/10.30525/978-9934-26-080-3-13

\title{
СОЦІАЛЬНА ВІДПОВІДАЛЬНІСТЬ В УКРАЇНІ ЧЕРЕЗ ПРИЗМУ ОРГАНІЗАЦІЇ БЛАГОДІЙНОЇ ДІЯЛЬНОСТІ
}

Організація соціальної відповідальності переживає суттєву трансформацію в умовах формування соціальної структури національної економіки.

Для створення суспільно відповідального суспільства важливо отримуватися умов соціальної відповідальності бізнесу та юридичних осіб.

Соціальна відповідальність - це етична теорія, згідно з якою люди відповідають за виконання свого громадянського обов'язку, а дії окремої людини повинні приносити користь усьому суспільству. Таким чином, повинен існувати баланс між економічним зростанням та добробутом суспільства та навколишнього середовища. Якщо ця рівновага підтримується, то соціальна відповідальність досягається [1].

Теорія соціальної відповідальності побудована на системі етичних відносин, в якій рішення та дії повинні бути етично підтверджені. Якщо дія чи рішення завдають шкоди суспільству чи навколишньому середовищу, тоді це буде вважатися соціально безвідповідальним.

Моральні цінності, які притаманні суспільству, створюють відмінності між правильним і неправильним. Таким чином, соціальна справедливість вважається (більшістю) «правильною», але частіше за все ця «справедливість» відсутня. Кожна людина повинна діяти таким чином, щоб було корисно не лише для особистості, але й для суспільства в цілому, беручи на себе відповідальність за прийняті рішення. Таке трактування 
соціальної відповідальності є загальним і стосується як фізичних так і юридичних осіб.

В свою чергу підприємства, які практикують корпоративну соціальну відповідальність, націлені на покращення спільнот, національної економіки чи навколишнього середовища.

Корпоративна соціальна відповідальність (КСВ) - це вид саморегулювання бізнесу, метою якого є соціальна підзвітність. Не існує жодного «правильного» способу, яким компанії можуть практикувати КСВ; багато корпоративних ініціатив 3 КСВ прагнуть позитивно сприяти громадськості, економіці чи навколишньому середовищу. У сучасному соціально свідомому середовищі співробітники та клієнти надають перевагу роботі та витраченню своїх грошей на підприємства, котрі надають пріоритет КСВ [2].

У міру розширення використання корпоративної відповідальності стає все більш важливим мати соціально свідомий імідж. Споживачі, співробітники та зацікавлені сторони ставлять пріоритет щодо корпоративної соціальної відповідальності при виборі бренду чи компанії, і вони притягають корпорації до відповідальності за здійснення соціальних змін своїми діловими переконаннями, практикою та прибутком.

Дослідження Cone Communications показало, що понад 60\% американців сподіваються, що бізнес буде стимулювати соціальні та екологічні зміни за відсутності державного регулювання. Майже 90\% опитаних споживачів заявили, що придбають товар, оскільки компанія підтримує проблему, яка їх турбує. Що ще важливіше, майже 75\% заявили, що відмовляться купувати у компаніі, якщо дізнаються, що компанія підтримує проблему, що суперечить їхнім власним переконанням.

Споживачі не єдині, кого приваблює бізнес, який віддає гроші на соціальні цілі, актуальними гравцями із соціально відповідальними компаніями стають інвестори, посередницькі компанії та держава.

Одним із шляхів реалізації програм із створення соціально сприятливого іміджу компанії $\epsilon$ їх участь у благодійній 
діяльності, тобто створення позитивної думки про бізнес у суспільній свідомості шляхом інтерпретації та використання місії благодійних організацій у діяльності бізнесу.

Розвинуте суспільство акцентує увагу не лише на економічному зростанні як основній цілі розвитку економічних систем, але i на соціальному аспекті розвитку. Така місія розвитку громадянського суспільства визначається потребою подолання «відмов» ринку та необхідністю формування потужних моральноетичних платформ бізнесу країн особливо за високих темпів економічного зростання.

Реалізація благодійної діяльності як одного із напрямів розвитку підприємств змінювалась впродовж усього циклу формування підприємництва в Україні: починаючи від прийняття законів «Про підприємництво» (№ 698-XII від 7.02.1991) [3], Господарського кодексу [4] та супровідних актів, які визначали шляхи легального здійснення благодійництва в режимі пільгового оподаткування об'єктів та суб'єктів благодійної діяльності, зокрема: Закон України від 28 грудня 1994 р. «Про оподаткування прибутку підприємств» [5], Постанова Кабінету Міністрів України від 24 липня 1993 р. «Про впорядкування, приймання та розподіл гуманітарної допомоги» [6], Указ Президента України від 12 серпня 1995 р. «Про пільги щодо оподаткування добровільних пожертвувань юридичних та фізичних осіб» [7] тощо.

Інтернаціоналізація національних економік та створення глобального соціокультурного простору визначає потребу врахування особливостей формування систем соціальної відповідальності бізнес-структур та держави країн-контрагентів. В країнах Свропейського Союзу розвиток благодійної діяльності бізнесу у формі благодійництва та меценатства ініціюється державою. Такими заходами можуть бути: стимулювання спонсорства шляхом вилучення суми, витраченої на рекламу та маркетингові операції, з обсягів, що обкладаються податком (Бельгія, Велика Британія), відсутність оподаткування маркетингових витрат, які ідуть на благодійні цілі (Австрія Франція). В Угорщині дозволено 
відрахування на меценатство $70 \%$ прибутку підприємств і компаній, Німеччині - 33,2 \% [8].

В Україні основним фактором, який мотивує суб'єктів господарювання здійснювати пожертви $€$ результативність діяльності благодійної організації, інші - залежать від сприйняття громадян інституту благодійної діяльності у державі. Фізичні та юридичні особи, які віддають частину своїх прибутків, заощаджень або майна на благодійну діяльність, користуються податковими та іншими пільгами відповідно до законодавства України (рис. 1).

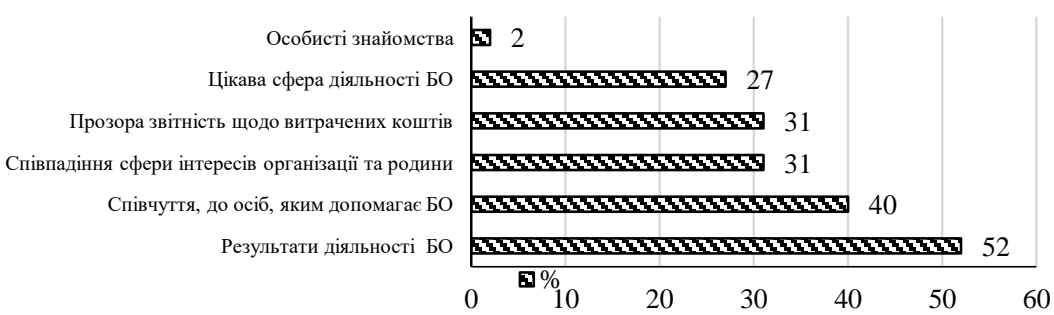

\section{Рис. 1. Основні фактори, що мотивують громадян робити пожертви}

Серед причин небажання брати участь у благодійницькій діяльності українці відзначають недостатність коштів, недовіру до отримувачів благодійної допомоги, невіру в те, що така діяльність може мати реальний вплив на ситуацію, вважають, що саме держава має турбуватися про вирішення проблем [8].

Отже, на тлі позитивного розвитку благодійництва в Україні рівень залучення людей, які регулярно займаються благодійною чи волонтерською діяльністю, залишається ще низьким.

\section{Література:}

1. URL: https://www.pachamama.org/social-justice/social-responsibility-andethics.

2. URL: https://www.businessnewsdaily.com/4679-corporate-social-responsibility.html. 
3. Закон України «Про підприємництво». URL: https://zakon.rada.gov.ua/ laws/show/698-12\#Text.

4. Господарський кодекс. У країни URL: https://zakon.rada.gov.ua/ laws/show/436-15\#Text.

5. Про оподаткування прибутку підприємств: Закон України від 22.05.1997 № 334/94-ВР. Відомості Верховної Ради Украӥни. 1995. № 4. Ст. 28.

6. Про впорядкування, приймання та розподіл гуманітарної допомоги: Постанова Кабінету Міністрів України від 24.07.1993 № 573. База даних «Законодавство України» / ВР України. URL: http://zakon.rada.gov.ua/laws/ show/573-93-\%D0\%BF.

7. Про пільги щодо оподаткування добровільних пожертвувань юридичних та фізичних осіб: Указ Президента України від 12.08.1995 № 750/95. База даних «Законодавство України» / ВP України. URL: http://zakon0.rada.gov.ua/laws/ show/750/9.

8. Розвиток благодійництва в сучасній Україні. Аналітична записка. URL: http://old2.niss.gov.ua/articles/1367. 